\title{
RELATIONSHIP BETWEEN FOREIGN DIRECT INVESTMENT AND DOMESTIC INVESTMENT IN CENTRAL AND EASTERN EUROPE DEPENDING ON OPENNESS OF THE ECONOMY
}

\author{
[Vzt’ah medzi priamymi zahraničnými investíciami a domácimi investíciami \\ v regióne strednej a východnej Európy v závislosti na otvorenosti ekonomik]
}

\author{
Zuzana Szkorupová ${ }^{1}$ \\ ${ }^{1}$ Slezská univerzita, Obchodně podnikatelská fakulta, Univerzitní nám. 1934/3,733 40 Karviná \\ Email:szkorupova@opf.slu.cz
}

\begin{abstract}
Foreign direct investment is discussed on various levels. Basically we speak about positive and negative effects that might be expressed directly or indirectly. In evaluating the impact of foreign direct investment on development, however, a key question is whether foreign direct investment crowd in domestic investment, or foreign direct investment crowd out domestic investment. This paper focuses on research of FDI effects in Central and Eastern Europe. The aim of this paper is to examine whether foreign direct investment in selected countries of Central and Eastern Europe crowds in or crowds out domestic investment. For this purpose we apply theoretical model of investment that includes foreign direct investment as an exogenous variable. Annual data were tested with panel regression with fixed effects for the period 1993 - 2011. Detected results indicate that in all specified areas, the effect of extrusion of domestic investments prevails.
\end{abstract}

Keywords: foreign direct investment, domestic investment, crowding out effect, crowding in effect, panel data analysis, Central and Eastern Europe.

JEL classification: F21, F23

Doručeno redakci: 21.7.2014; Recenzováno: 6.8.2014; 5.9.2014; Schváleno k publikování: 11.2.2015

\section{Úvod}

Priame zahraničné investície (PZI) zohrali významnú rolu v krajinách strednej a východne Európy (SVE) v období prechodu $\mathrm{z}$ centrálne plánovaného hospodárstva $\mathrm{k}$ tržnému, ktoré bolo sprevádzané vlnou privatizácie strategických podnikov. Ako uvádza Srholec (2004), priame zahraničné investície nie sú len charakteristickým rysom postupujúcej globalizácie, ale na sklonku 90. rokov 20. storočia sa stali sprievodným znakom dokončenia transformačných zmien. Následne v súvislosti s prijímaním významných reforiem sa stal región strednej a východnej Európy atraktívnym i pre investorov realizujúcich investície na zelenej lúke. Prílev priamych zahraničných investícií je podporovaný zo strany vlády jednotlivých štátov i investičnými stimulmi. Všeobecne býva tvrdené, že prílev zahraničného kapitálu je zárukou ekonomického rastu, poklesu nezamestnanosti, rastu exportu, získania nového know how či technológií.

V prvej polovici 90. rokov môžeme prílev PZI do regiónu SVE označit’ za nízky. Postupom času, v dôsledku realizovaných reforiem a postupnej privatizácie sa začalo tempo rastu prílevu PZI zvyšovat'. Na raste prílevu PZI celkovo i na zelenej lúke sa tiež pozitívne podpísal vstup jednotlivých štátov z regiónu SVE do Európskej únie. V tejto súvislosti tiež napríklad uvádza Roubíčková (2012), že v roku 2005 došlo z vtedajšieho pohl'adu k historicky najväčšiemu prílevu PZI do českej ekonomiky. Finančná kríza a jej následky, ktoré sa začali prejavovat' v tomto regióne v roku 2008 a 2009, sa pričinili o zníženie prílevu PZI. K opätovnému nárastu prílevu PZI v regióne strednej a východnej Európy dochádza až v roku 2011. 
Problematika priamych zahraničných investícií je často diskutovanou témou na rôznych úrovniach. Predmetom odborných ekonomických či politických debát sa stávajú dopady priamych zahraničných investícií na hostitel'skú krajinu. Vo všeobecnosti v literatúre pretrváva akýsi konsenzus o pozitívnych efektoch PZI na domácu ekonomiku. Závery empirických štúdií však potvrdzujú, že efekty PZI nie sú jednoznačné. Niektoré efekty sú dokonca t’ažko kvantifikovatel'né. Rozdiely v záveroch tiež odrážajú dostupnost' a kvalitu dát, dížku časových radov či použité metódy výskumu.

Ekonomické efekty PZI môžu byt' mikroekonomické a makroekonomické. Príkladom mikroekonomických efektov je vplyv nadnárodných spoločností na domáce konkurenčné prostredie. K makroekonomickým efektom sa radia napríklad dopady na ekonomický rast, účty platobnej bilancie, zahraničný obchod krajiny alebo zamestnanost'. Ďalej efekty PZI môžu pôsobit' na ekonomiku krajiny priamo či nepriamo a zároveň pozitívne či negatívne. Ako príklad priamych pozitívnych účinkov je možné uviest' podporu ekonomického rastu, technologický transfer, know how v oblasti manažmentu, nedlhové financovanie deficitu bežného účtu platobnej bilancie, podporu rastu exportu. K priamym negatívnym efektom PZI sa napríklad radí zhodnotenie kurzu domácej meny, vynútený rast peňažnej zásoby a tlaky na infláciu. Nepriame pozitívne účinky PZI na domáce investície sa prejavujú v prelievaní pozitívnych efektov na domáce podnikatel'ské prostredie a vo vytváraní väzieb medzi nadnárodnými spoločnost’ami a domácimi podnikmi. Negatívnym nepriamym efektom PZI je pravý opak.

Efekty PZI sa môžu prejavovat' v celej rade oblastí a aspektov. Ciel'om článku je zistit', či priame zahraničné investície vt’ahujú (CI - efekt) alebo vytláčajú (CO - efekt) domáce investície v regióne strednej a východnej Európy. Prílev PZI môže na jednej strane pôsobit' na domáce investície tak, že ich stimuluje, a teda hovorí sa o efektoch vt'ahovania domácich investícií priamymi zahraničnými investíciami. Na druhej strane môžu PZI vytláčat' domáce investície a takto pôsobit' negatívne na domáce podnikatel'ské prostredie. Za účelom naplnenia ciel'a bude článok rozdelený do štyroch kapitol. Prvá kapitola sa venuje teoretickému pohl'adu na problematiku efektov PZI v súvislosti s dopadom na domáce investície. Druhá kapitola poskytuje prehl'ad relevantnej literatúry k danej problematike. Tretia kapitola je venovaná špecifikácii modelu a použitým údajom $\mathrm{k}$ testovaniu spomínaných efektov. Štvrtá kapitola poskytuje prehl’ad empirických výsledkov získaných testovaním.

\section{Teoretický pohl'ad na problematiku efektov PZI na domáce investície}

Priame zahraničné investície nesú so sebou určité výhody ako aj nevýhody, rovnako ako pre krajinu investora tak aj pre krajinu hostitel'skú. Ex-ante platí, že obe z týchto krajín predpokladajú, že prínosy z PZI budú väčšie ako náklady, ktoré pri ich realizácií vznikajú. To však nie je zárukou a efekty PZI ex-post môžu byt' opačné.

Lall a Streeten (1977) tvrdia, čo sa týka pozitívnych efektov PZI na hostitel'skú krajinu, že na základe princípov neoklasickej ekonómie, PZI prispievajú k zvyšovaniu dôchodkov a blahobytu spoločnosti $\mathrm{v}$ hostitel'skej krajine, a to v prípade kedy optimálne podmienky nie sú významne deformované protekcionizmom, monopolmi a externalitami. Tieto tvrdenia sú na druhej strane spochybňované argumentmi, že nadnárodné spoločností existujú a fungujú najmä kvôli tržným nedokonalostiam čo spochybňuje to, že PZI vedú k zvyšovaniu životnej úrovne obyvatel'stva. Z toho celého vyplýva, že neplatí všeobecne, že PZI vždy zaručene zvyšujú životnú úroveň krajiny. Nadnárodné spoločnosti sa totiž môžu zmocňovat' trhu na úkor domácich firiem, a tak ich vytlačovat' $\mathrm{z}$ trhu, čo nepôsobí pozitívne na celkovú efektívnost' fungovania ekonomiky krajiny. 
Základné členenie efektov PZI je na (i) politické, (ii) sociálne a (iii) ekonomické. O ekonomických efektoch PZI môže byt' diskutované na makro a mikro úrovní. Na makro úrovní sa hovorí o efektoch PZI napríklad v prípade nedostatku kapitálu a nízkej zamestnanosti v hostitel'skej krajine, kedy PZI môžu prispiet' v tomto ohl'ade k zvýšeniu produkcie ako aj k zvýšeniu zamestnanosti. Ako d’alší príklad efektov, ktoré sa prejavia z makroekonomického hl'adiska je možné spomenút' vplyv PZI na jednotlivé účty platobnej bilancie. Ďalej to môže byt' vplyv PZI na export a import. V tomto smere záleží na tom, že či PZI, ktoré smerujú do hostitel'skej krajiny, tam mieria za účelom nahradenia predošlého exportu alebo s ciel'om výrobky vyrobené v hostitel'skej krajine d'alej exportovat'. V prvom prípade nedochádza $\mathrm{k}$ vplyvu na rast exportu, $\mathrm{v}$ druhom prípade áno. Na mikro úrovní môže byt' zmienený príklad vplyvu PZI na konkurenčné prostredie v hostitel'skej krajine. PZI môžu viest' ako ku zlepšeniu konkurenčného prostredia, tak aj opačne k jeho zhoršeniu. Ide o vt’ahovanie či vytláčanie domácich firiem z trhu. Efekty PZI na mikro úrovní sa týkajú priamo firiem a odvetví. Pre potreby tohto článku budú z teoretického pohl'adu vymedzené len tie efekty priamych zahraničných investícií, ktoré sa dotýkajú vplyvu na domáce investície a teda domáce podnikatel'ské prostredie.

\subsection{Priame zahraničné investície a medziodvetvové väzby}

Ide o efekty priamych zahraničných investícií v oblasti nadväzovania spolupráce $\mathrm{s}$ inými miestnymi firmami $v$ hostitel'skej krajine. V prípade nadväzovania spolupráce s miestnymi dodávatel'mi ide o väzby smerom dozadu (backward linkages) a v prípade spolupráce s miestnymi distribútormi o väzby smerom dopredu (forward linkages). K takejto spolupráci nedochádza vždy. Ak totiž materská spoločnost' alebo iné dcérske spoločností sú zamerané na výrobu medziproduktov a materiálov, ktoré potrebuje zahraničná firma (PZI) v hostitel'skej krajine k d'alšej výrobe, bude odoberat' tieto vstupy do výroby od nich. Rovnako niekedy vel'ká investícia zahraničného investora priláka do krajiny aj výrobcov medziproduktov potrebných pre jeho výrobu.

Petrochilos (1989) upozorňuje na to, že tento efekt PZI býva často krát zveličovaný, a to najmä v súvislosti s rozvíjajúcimi sa ekonomikami. Podl'a jeho tvrdení je väčšina nadnárodných spoločností pôsobiacich v zahraničí dostatočne vertikálne integrovaná, čo obmedzuje priestor pre rozvíjanie odberatel'sko-dodávatel'ských väzieb s miestnymi dodávatel'mi. V mnohých prípadoch navyše dochádza k prevzatiu miestneho dodávatel'a, a to za účelom minimalizovania rizika zo vzájomnej spolupráce.

\subsection{Efekty priamych zahraničných investícií na tržnú štruktúru}

Vstup zahraničného investora do hostitel'skej krajiny môže mat' významné dopady na tržnú štruktúru v danom odvetví, do ktorého vstupuje. PZI môžu mat' dvojaký vplyv na tržnú štruktúru. Za prvé PZI môžu vt'ahovat' podniky na trh a teda vylepšovat' konkurenčné prostredie a hospodársku sút'až alebo naopak podniky z trhu vytlačovat', a teda vytvárat' prostredie monopolu alebo oligopolu.

Kindleberger (1969) vo svojej práci vyjadruje tvrdenie, že hlavným efektom PZI je vytváranie priestoru pre konkurenciu. Odôvodňuje to tým, že PZI realizované v hostitel'skej krajine sa opierajú o silnú materskú spoločnost' a tak môžu účinne konkurovat' silným firmám s oligopolným postavením na trhu v hostitel'skej krajine, a tak zlomit' ich dominantné postavenie, čo má za následok efektívnejšiu alokáciu zdrojov v krajine.

Úvaha vychádzajúca z tvrdenia Kindlebergera predpokladá existenciu dominantnej firmy na trhu v hostitel'skej krajine, ktorej dominantné postavenie príchod PZI narušuje a vylepšuje 
konkurenčné prostredie. Pokial' však na trhu pôsobia malé miestne firmy, ktoré nedokážu konkurovat' zahraničnému investorovi, potom dochádza k vytláčaniu malých firiem $\mathrm{v}$ hostitel'skej krajine z trhu a zahraničná spoločnost' získava dominantné postavenie na trhu. Reuber et al. (1973) tvrdia, že PZI môžu bránit' rozvoju domácich firiem a zvyšovat' koncentráciu $v$ hostitel'skej krajine tlakom na fúzie miestnych firiem. Newfarmer a Mueller (1975) dokazujú vo svojej práci na príklade Mexika a Brazílie, že vstup nadnárodných spoločností do rozvojových krajín spôsobuje tvorbu oligopolov v týchto krajinách.

\section{Prehl'ad relevantnej literatúry}

Počet štúdií zaoberajúcich sa vplyvom priamych zahraničných investícií na domáce investície v strednej a východnej Európe nie je taký vel'ký v porovnaní so štúdiami riešiacimi tuto problematiku v Ázií či Amerike. Tento fakt je zrejme tiež spôsobený dostupnost'ou časových radov potrebných pre výskum.

Existujú empirické práce, ktoré k tomuto výskumu využívajú makroekonomické veličiny, ale sú tiež prístupy využívajúce firemné dáta. Vzhl'adom na problémy spôsobené s dostupnost'ou dát na mikro úrovni, bude za účelom výskumu využitý model založený na makro dátach. $\mathrm{Z}$ tohto dôvodu bude $\mathrm{v}$ tejto kapitole venovaná pozornost' záverom štúdií, ktoré pristupujú $\mathrm{k}$ riešeniu tejto problematiky prostredníctvom využitia dát na makroekonomickej úrovni.

Známou empirickou prácou je štúdia Agosina a Mayera (2000). Model nimi zostrojený vychádza z identity, že celkové investície sú tvorené súčtom domácich a zahraničných investícií. Postupným rozpracovaním modelu bola zostrojená rovnica pre regresnú analýzu, kde vysvetl'ovanou premennou sú celkové investície a nezávislé veličiny sú priame zahraničné investície, domáce investície a ekonomický rast. Výskum realizovali na krajinách z troch regiónov Latinskej Ameriky, Afriky a Ázie v časovom období 1970 - 1996. Výpočty boli uskutočnené pomocou panelovej regresie, kde prierezovými veličinami boli jednotlivé štáty. Ďalej bol zostrojený koeficient, ktorý po dosadení výsledkov z panelovej regresie vyhodnotil prítomnost' efektu vt’ahovania, vytláčania alebo neutrálneho efektu PZI na domáce investície. Výsledkom ich výskumu bolo preukázanie efektu vt'ahovania domácich investícií priamymi zahraničnými investíciami v regióne Ázie a Afriky. Efekt vytláčania domácich investícií bol zistený v Latinskej Amerike. Tento výskum zopakovali Agosin a Machado (2005), kedy na vzorke krajín z Latinskej Ameriky, Ázie a Afriky za roky 1971 - 2000 skúmali efekty vt’ahovania a vytláčania. Závery ich výskumu preukázali rovnaké výsledky ako v predchádzajúcom výskume Agosin a Mayer. Negatívne výsledky zistené pre región Latinskej Ameriky zdôvodňujú zle nastavanou politikou štátu pri získavaní PZI. Na tento výskum naviazali a na podmienky tranzitívnych ekonomík mierne model upravili Mišun a Tomšík (2002). Použitím rovnakého typu dát a regresnej analýzy skúmali efekty vt’ahovania a vytláčania domácich investícií v Českej republike, Pol'sku a Mad'arsku. Odhad zrealizovali za časový úsek 1993 - 2000 v Českej republike a 1990 - 2000 v Pol'sku a Mad'arsku. Pozitívny vplyv PZI na domáce investície zistili v prípade Česka a Mad’arska a naopak negatívne pôsobia PZI na domáce investície v Pol'sku. Efekt vytláčania v Pol'sku pripisujú prevažne počiatočnej transformačnej recesií. Rovnaký prístup k výskumu vplyvov PZI na domáce investície ako Mišun a Tomšík zaujal a z modelu Agosin a Mayer vychádzal Titarenko (2006). Výskum zameral na Lotyšsko a časové obdobie 1995 - 2004. Výsledkom bolo zistenie efektu vytláčania domácich investícií priamymi zahraničnými investíciami v sledovanom období. Ako jeden z dôvodov negatívneho efektu na domáce investície uvádza, že v posledných 10 rokoch sledovaného obdobia bola v Lotyšsku nízka intenzita prílevu PZI a malý prílev PZI nemôže prispiet' k pozitívnemu efektu vt'ahovania. Ako d'alší dôvod Titarenko uvádza fakt, že PZI plynú v Lotyšsku do najdynamickejších odvetví hospodárstva 
ako sú plynárenský priemysel, telekomunikácie, kovospracujúci priemysel, jednoducho do oblastí, kde majú monopolné postavenie resp. kde je oligopolná tržná štruktúra. $\mathrm{V}$ mnohých prípadoch dochádza k preberaniu domácich podnikov zahraničnými podnikmi, a to $\mathrm{z}$ dôvodu ich neefektívneho fungovania a nedostatočnej konkurencie schopnosti. $Z$ týchto dôvodov prílev PZI do Lotyšska len zriedka stimuluje domáce investície. Morrissey et al. (2008) využíva model Agosina a Mayera k dokazovaniu efektov vt'ahovania a vytlačovania domácich investícií v 36 nízko a stredne príjmových krajinách z Latinskej Ameriky, Afriky, Ázie a strednej a východnej Európy. Konkrétne v modeli figuruje 13 krajín z Latinskej Ameriky, 8 krajín z Ázie, 10 zo strednej a východnej Európy a 5 z Afriky. Výskum je realizovaný za časové obdobie 1995 - 2001. K odhadom je využitá panelová regresia. Výsledkom je zistenie, že priame zahraničné investície majú tendenciu vytláčat' domáce investície a táto tendencia je silnejšia čím je v štáte vyššia moc vlády.

\section{3 Špecifikácia modelu a dáta}

Vzhl'adom na dostupnost' vstupných dát a prehl'adnost' modelu bol pre výskum v regióne SVE zvolený model, ktorý bol pôvodne vytvorený autormi Manuel R. Agosin a Ricardo Mayer (2000). Následne bol upravený na podmienky tranzitívnych ekonomík Mišunom a Tomšíkom (2002). Výsledný model, ktorý bude použitý k odhadu efektov priamych zahraničných investícií v regióne SVE má nasledujúci tvar:

$I_{i, t}=\beta_{0}+\beta_{1} F_{i, t}+\beta_{2} F_{i, t-1}+\beta_{3} F_{i, t-2}+\beta_{4} I_{d, i, t-1}+\beta_{5} I_{d, i, t-2}+\beta_{6} I_{d, i, t-3}++\beta_{7} G_{i, t-1}+$ $\beta_{8} G_{i, t-2}+\beta_{9} G_{i, t-3}+\varepsilon_{i, t}$

kde $F$ predstavuje podiel priamych zahraničných investícií na HDP, $I_{d}$ podiel domácich investícií na HDP, $G$ je tempo ekonomického rastu a $\varepsilon$ je štatistická chyba. Identifikátor $i$ označuje krajinu v paneli a $t$ čas.

K určeniu efektov vt'ahovania alebo vytláčania domácich investícií priamymi zahraničnými investíciami bude využitý koeficient v tvare:

$$
\pi=\frac{\beta_{1}+\beta_{2}+\beta_{3}}{1-\left(\beta_{4}+\beta_{5}+\beta_{6}\right)}
$$

Kritériom použitým pre determináciu efektu vt’ahovania alebo vytlačovania domácich investícií, je hodnota koeficientu $\pi$. V úvahu prichádzajú tri možnosti:

- Ked' koeficient $\pi=1$. Znamená to, že z dlhodobého hl'adiska zvýšenie PZI o jednotku vedie k zvýšeniu celkových investícií rovnako o jednotku.

- V prípade, že koeficient $\pi>1$ sa hovorí o vt'ahovaní domácich investícií zahraničnými investíciami. Z dlhodobého hl'adiska to znamená, že jedna dodatočná jednotka PZI sa prejaví viac než jednou dodatočnou jednotkou v celkových investíciach.

- Pokial' je koeficient $\pi<1$, potom je to dôkaz o tom, že domáce investície sú vytláčané zahraničnými. Z dlhodobého hl'adiska to značí, že jedna dodatočná jednotka PZI vedie k prírastku celkových investícií o menej než jednu jednotku.

Ak sa dlhodobý efekt PZI prejavuje tak, že vt'ahuje domáce investície, potom sa hovorí o pozitívnych vedl'ajších efektoch priamych zahraničných investícií. Ak dlhodobo PZI vedú k tomu, že vytláčajú domáce investície, potom sú vedl'ajšie efekty PZI negatívne.

Model je testovaný na ročných údajoch za časové obdobie 1993 - 2011. Dáta o vývoji prílevu PZI/HDP, vývoji tempa rastu HDP a tvorbe hrubého fixného kapitálu/HDP boli získané 
zo štatistickej databázy Svetovej banky World databank. Odhady boli uskutočnené na základe panelovej regresie v programe Eviews 7. Použité boli obe varianty panelovej regresie ako s fixnými tak náhodnými efektmi. Na základe Hausmanovho testu, ktorý vykazoval značné rozdiely v koeficientoch, bol využitý panelový model s fixnými efektmi. Konkrétne boli zvolené prierezové efekty fixné a časové efekty žiadne.

Pred samotnou realizáciou panelovej regresie je potrebné otestovat' stacionaritu jednotlivých používaných časových radov. Jedná sa o rozhodnutie o existencii jednotkového koreňa. Za týmto účelom bol využitý Levin, Lin, Chu test (LLC test), ktorý preukázal u všetkých troch časových radov, že sú stacionárne na svojich hodnotách I(0). Vzhl'adom k tomuto faktu môže byt' uskutočnená analýza panelových dát.

Testovanie efektov vt'ahovania a vytláčania domácich investícií priamymi zahraničnými investíciami bude zrealizované na dvoch úrovniach. Najskôr budú krajiny rozdelené do regiónov z geografického hl'adiska. Pôjde o región Vyšehradskej štvorky (Česká republika, Mad'arsko, Pol'sko, Slovensko), región tvorený vybranými krajinami Balkánu (Bulharsko, Chorvátsko, Rumunsko, Slovinsko) a región tvorený pobaltskými krajinami (Estónsko, Litva, Lotyšsko). K členeniu krajín $\mathrm{z}$ geografického hl'adiska je v súvislosti s tým, že investori zvyknú považovat' viacero susediacich krajín za homogénny celok. Následne pôjde o výskum v krajinách, ktoré boli rozčlenené do skupín na základe prílevu PZI v pomere k HDP. Pomer prílevu PZI na HDP môže byt' vnímaný ako ukazovatel' otvorenosti ekonomiky. V tejto súvislosti sa dá predpokladat', že efekty PZI na domáce investície sa budú prejavovat' odlišne v štátoch s vyššou mierou otvorenosti ekonomík ako v štátoch, kde je miera otvorenosti ekonomiky nižšia.

\section{Empirická analýza}

\subsection{Testovanie efektov CO a CI v skupinách krajín podl’a geografického členenia}

Testovanie efektov vt'ahovania a vytláčania domácich investícií PZI prebehlo na základe vyššie špecifikovaného modelu. Výsledky panelových regresií za jednotlivé zoskupenia štátov sú uvedené v Tabul'ke 1. Výpočet regresnej analýzy je dôležitý pre potreby výpočtu koeficientu $\pi$, ktorý vypovedá o efektoch PZI na domáce investície. Hodnoty adjustovaného $R^{2}$ potvrdzujú relatívne vysokú vypovedaciu schopnost' všetkých troch modelov. Jeho hodnota sa pohybuje od $78,4 \%$ v prípade Pobaltska po $83,9 \%$ v prípade V4. Rovnako výsledky Durbin-Watsonovho testu hovoria o tom, že rezíduá nie sú zat’ažené autokoreláciou. 
Tabul'ka 1: Empirické výsledky testovania modelu v jednotlivých regiónoch

\begin{tabular}{|c|c|c|c|}
\hline Premenná & Balkán & Pobaltsko & V4 \\
\hline \multirow[t]{2}{*}{$F_{t}$} & $0,144^{\mathrm{c}}$ & $0,286^{\mathrm{a}}$ & $-0,021$ \\
\hline & $(1,892)$ & $(2,601)$ & $(-0,628)$ \\
\hline \multirow[t]{2}{*}{$F_{t-1}$} & 0,099 & 0,034 & 0,045 \\
\hline & $(0,979)$ & $(0,276)$ & $(1,239)$ \\
\hline \multirow[t]{2}{*}{$\mathrm{F}_{\mathrm{t}-2}$} & 0,099 & $-0,175$ & $-0,094 b$ \\
\hline & $(1,012)$ & $(-1,393)$ & $(-2,452)$ \\
\hline \multirow[t]{2}{*}{$\mathrm{I}_{\mathrm{t}-1}$} & $0,385^{\mathrm{b}}$ & $0,494^{\mathrm{b}}$ & $1,067^{\mathrm{a}}$ \\
\hline & $(2,369)$ & $(2,075)$ & $(7,924)$ \\
\hline \multirow[t]{2}{*}{$I_{t-2}$} & $-0,138$ & 0,049 & $-0,546^{\mathrm{a}}$ \\
\hline & $(-0,728)$ & $(0,201)$ & $(-2,882)$ \\
\hline \multirow[t]{2}{*}{$\mathrm{I}_{\mathrm{t}-3}$} & $0,258^{\mathrm{c}}$ & 0,009 & 0,133 \\
\hline & $(1,764)$ & $(0,053)$ & $(0,348)$ \\
\hline \multirow[t]{2}{*}{$\mathrm{G}_{\mathrm{t}-1}$} & $0,301^{\mathrm{a}}$ & $0,300^{\mathrm{a}}$ & $-0,104$ \\
\hline & $(3,725)$ & $(2,717)$ & $(-1,065)$ \\
\hline \multirow[t]{2}{*}{$\mathrm{G}_{\mathrm{t}-2}$} & 0,133 & $-0,039$ & $0,200^{\mathrm{b}}$ \\
\hline & $(1,466)$ & $(-0,369)$ & $(2,168)$ \\
\hline \multirow[t]{2}{*}{$\mathrm{G}_{\mathrm{t}-3}$} & 0,042 & 0,008 & $-0,279^{\mathrm{a}}$ \\
\hline & $(0,481)$ & $(0,093)$ & $(-2,979)$ \\
\hline Upravené $\mathrm{R}^{2}$ & 0,834 & 0,784 & 0,839 \\
\hline DW štatistika & 2,039 & 2,218 & 2,059 \\
\hline
\end{tabular}

Zdroj: Výpočty autora.

Poznámka: hodnoty uvedené v zátvorkách predstavujú t-štatistiky, ,a“ “načí významnost’ na $1 \%$ hladine významnosti, „b“ “načí významnost' na $5 \%$ hladine významnosti, ,,c “ značí významnost' na $10 \%$ hladine významnosti.

Na základe výpočtu koeficientu $\pi$ bol vo všetkých troch regiónoch preukázaný negatívny efekt priamych zahraničných investícií na domáce investície. Inými slovami z dlhodobého hl'adiska pôsobia priame zahraničné investície negatívne na domáce podnikatel'ské prostredie a neprispievajú k zvyšovaniu celkových investícií. Najsilnejšie sa efekt vytlačovania domácich investícií priamymi zahraničnými investíciami prejavil v regióne Vyšehradskej štvorky. Najslabší efekt vytláčania bol zistený za vybrané štáty Balkánu. Spoločný negatívny výsledok prílevu PZI na domáce investície môže byt' odrazom neefektívnej politiky jednotlivých štátov pri získavaní zahraničných investorov. Kedy na jednej strane štáty v snahe prilákat' zahraničných investorov využívajú širokú škálu stimulov bez ohl'adu na to, aký dopad bude mat' prílev PZI na domáce podnikatel'ské prostredie, v ktorom sa nachádzajú vo väčšej miere malé a stredné firmy, ktoré nedokážu konkurovat' nadnárodným spoločnostiam $\mathrm{v}$ odvetví a ani im poskytovat' adekvátne služby subdodávatel'ov. Fakt, že najsilnejší efekt vytlačovania bol preukázaný v krajinách V4 a najslabší efekt vytláčania na Balkáne, môže súvisiet' so skutočnost'ou, že najsilnejšia intenzita prílevu PZI je práve do štátov V4. Naopak najslabšiu intenzitu prílevu PZI vykazuje región Balkánu. Výsledky testovania efektov CI - efektu a CO - efektu pre región V4, vybrané štáty Balkánu a pobaltské štáty sú uvedené v Tabul'ke 2. 
Tabul'ka 2: Efekty PZI na domáce investície v regiónoch SVE podl’a geografického členenia

\begin{tabular}{|l|l|l|}
\hline Skupina štátov & Koeficient $\pi$ & Dlhodobý efekt \\
\hline Balkán & 0,692 & CO - efekt \\
\hline Pobaltsko & 0,327 & CO - efekt \\
\hline V4 & $-0,201$ & CO - efekt \\
\hline
\end{tabular}

Zdroj: Výpočty autora.

\subsection{Testovanie efektov CO a CI v skupinách krajín podl’a pomeru prílevu PZI na HDP} Na základe pomeru prílevu PZI na HDP boli krajiny SVE rozdelené do troch skupín. Prvú skupinu tvoria krajiny s najvyšším pomerom prílevu PZI na HDP a naopak tretiu skupinu krajiny s najnižším týmto pomerom:

Skupina I.: Mad'arsko, Bulharsko, Estónsko

Skupina II.: Slovensko, Česká republika, Lotyšsko, Chorvátsko

Skupina III.: Rumunsko, Pol'sko, Litva, Slovinsko

Testovanie prebehlo podl'a vyššie špecifikovaného modelu. Výsledky regresnej analýzy panelových dát sa nachádzajú v Tabul'ke 3 . Hodnoty očisteného $R^{2}$ dokazujú, že vypovedacia schopnost' regresného modelu je vysoká. Na kvalitu modelu upozorňuje aj Durbin - Watsonov test, ktorý svojimi výslednými hodnotami potvrdzuje, že rezíduá nie sú autokorelované.

Tabul'ka 3: Empirické výsledky testovania modelu na základe PZI/HDP

\begin{tabular}{|c|c|c|c|}
\hline Premenná & Skupina I. & Skupina II. & Skupina III. \\
\hline \multirow[t]{2}{*}{$F_{t}$} & 0,030 & 0,132 & $0,270^{\mathrm{c}}$ \\
\hline & $(0,717)$ & $(1,260)$ & $(1,887)$ \\
\hline \multirow[t]{2}{*}{$\mathrm{F}_{\mathrm{t}-1}$} & 0,034 & $-0,036$ & $-0,044$ \\
\hline & $(0,726)$ & $(-0,317)$ & $(-0,272)$ \\
\hline \multirow[t]{2}{*}{$\mathrm{F}_{\mathrm{t}-2}$} & 0,012 & $-0,251^{b}$ & 0,154 \\
\hline & $(0,236)$ & $(-2,385)$ & $(1,018)$ \\
\hline \multirow[t]{2}{*}{$\mathrm{I}_{\mathrm{t}-1}$} & $0,635^{\mathrm{b}}$ & $0,788^{\mathrm{a}}$ & $0,721^{\mathrm{a}}$ \\
\hline & $(2,535)$ & $(5,621)$ & $(3,355)$ \\
\hline \multirow[t]{2}{*}{$\mathrm{I}_{\mathrm{t}-2}$} & 0,096 & $-0,093$ & $-0,326$ \\
\hline & $(0,337)$ & $(-0,517)$ & $(-1,304)$ \\
\hline \multirow[t]{2}{*}{$I_{t-3}$} & $-0,070$ & 0,055 & 0,109 \\
\hline & $(-0,367)$ & $(0,429)$ & $(0,583)$ \\
\hline \multirow[t]{2}{*}{$\mathrm{G}_{\mathrm{t}-1}$} & $0,405^{\mathrm{a}}$ & $0,161^{\mathrm{b}}$ & 0,152 \\
\hline & $(3,492)$ & $(1,853)$ & $(1,311)$ \\
\hline \multirow[t]{2}{*}{$\mathrm{G}_{\mathrm{t}-2}$} & $-0,074$ & 0,060 & 0,019 \\
\hline & $(-0,599)$ & $(0,691)$ & $(0,184)$ \\
\hline \multirow[t]{2}{*}{$\mathrm{G}_{\mathrm{t}-3}$} & 0,023 & $-0,193^{b}$ & $-0,013$ \\
\hline & $(0,196)$ & $(-2,077)$ & $(-0,176)$ \\
\hline Upravené $\mathrm{R}^{2}$ & 0,849 & 0,761 & 0,651 \\
\hline DW štatistika & 2,007 & 2,134 & 1,992 \\
\hline
\end{tabular}

Zdroj: Výpočty autora.

Poznámka: hodnoty uvedené v zátvorkách predstavujú t-štatistiky, ,a“ “ značí významnost' na $1 \%$ hladine významnosti, „b“ “načí významnost’ na $5 \%$ hladine významnosti, „c“ značí významnost’ na $10 \%$ hladine významnosti. 
Následne na základe výsledkov panelovej regresie bol vypočítaný koeficient $\pi$, na základe ktorého bolo rozhodnuté o efektoch priamych zahraničných investícií na domáce investície v jednotlivých vytvorených skupinách. Testovanie neprinieslo žiadne zmeny v záveroch plynúcich z výsledkov prvého testovania. Výsledky testov sú zhrnuté v Tabul'ke 4.

Dalo by sa očakávat', že výsledky efektov PZI na domáce investície budú odlišné v súvislosti s rozdielnymi hodnotami ukazovatel'a PZI/HDP, podl'a ktorého boli štáty zaradené do skupín. Avšak vo všetkých troch vytvorených skupinách bol efekt PZI na domáce investície negatívny. Najsilnejší efekt vytlačovania bol preukázaný v 2. skupine, kde sú zahrnuté krajiny s nižšou hodnotou PZI/HDP než v prvej skupine. Ak by sme predpokladali, že ukazovatel' PZI/HDP nám signalizuje mieru otvorenosti ekonomiky, tak výsledky testov nepotvrdzujú predpoklad, že čím je ekonomika otvorenejšia tým sú efekty PZI na domáce investície silnejšie. I ked' na druhej strane v skupine štátov, kde tento ukazovatel' zaznamenával v celom časovom období najnižšie hodnoty, bol preukázaný najslabší negatívny efekt PZI na domáce investície. $\mathrm{Na}$ základe týchto záverov sa teda nedá jednoznačne tvrdit', že čím je miera otvorenosti ekonomík väčšia, tým je i vyššia intenzita efektov PZI na domáce investície.

Tabul'ka 4: Efekty PZI na domáce investície v regiónoch SVE podl’a PZI/HDP

\begin{tabular}{|l|l|l|}
\hline Skupina štátov & Koeficient $\pi$ & Dlhodobý efekt \\
\hline Skupina I & 0,224 & CO - efekt \\
\hline Skupina II & $-0,168$ & CO - efekt \\
\hline Skupina III & 0,768 & CO - efekt \\
\hline
\end{tabular}

Zdroj: Výpočty autora

\section{Záver}

Výsledky testovania efektov CO - efektu a CI - efektu v regióne strednej a východnej Európy potvrdili, že priame zahraničné investície nepôsobia priaznivo na domáce podnikatel'ské prostredie a domáce podniky z trhu vytláčajú. Existuje niekol'ko vysvetlení negatívnych efektov PZI na domáce podnikatel'ské prostredie, ktoré sa dajú aplikovat' na región strednej a východnej Európy.

Jedným $\mathrm{z}$ argumentov je fakt, že počas transformačného obdobia $\mathrm{v}$ regióne strednej a východnej Európy boli PZI realizované prevažne formou privatizácie. Takto sa podarilo zahraničným investorom získat' podiel v strategických podnikoch ( $\mathrm{v}$ odvetviach telekomunikácií, plynárenského priemyslu, kovospracujúceho priemyslu a iných), ktoré majú na trhu postavenie monopolu či oligopolu a len t’ažko získavajú konkurenciu na strane domácich podnikatel'ských subjektov. V prípade, že vodvetví, do ktorého vstupuje nadnárodná spoločnost' už fungujú domáci podnikatelia dochádza $\mathrm{k}$ ich vytláčaniu alebo prevzatiu nadnárodnou spoločnost’ou. Domáce firmy nedokážu podnikat' tak efektívne a byt' konkurencieschopné nadnárodnej spoločnosti.

Ďalším dôvodom zistenia negatívnych výsledkov v regióne SVE je politika vlád, ktoré pripravujú stimuly pre zahraničných investorov. Takto vznikajú na jednej strane nadnárodné spoločnosti, ktoré sú dotované podnikatel'skými výhodami so strany štátu a na druhej strane domáce firmy bez akýchkol'vek výhod, s nízkym kapitálom a nízkou konkurencieschopnost'ou voči zahraničnými firmám. Navyše domáci podnikatelia nie sú atraktívni pre nadnárodne spoločnosti ani ako subdodávatelia, a to $\mathrm{z}$ dôvodu neplnia globálnych štandardov týkajúcich sa kvality subdodávok. Neexistuje oficiálna štatistika, kde by sa uvádzalo, kol'ko percent z celkových subdodávok pre nadnárodne spoločnosti, tvoria subdodávky od domácich podnikatel'ov. No napríklad Srholec (2004) uvádza, že vo väčšine prípadov PZI realizovaných na zelenej lúke je podiel subdodávok od domácich podnikatel’ov 
na celkových dodávkach nízky. Zahraniční investori majú tendenciu pritiahnut' so sebou do hostitel'skej krajiny i svojich dodávatel'ov. Tento príklad je typický napríklad pre automobilový priemysel v krajinách strednej a východnej Európy. Na zle realizovanú politiku pri získavaní zahraničných investícií upozorňuje viacero ekonómov, napríklad Kohout (2005), Agosin a Machado (2005), Titarenko (2006). Pri získavaní zahraničných investorov by malo ist' vláde o celkový efekt takejto investície na ekonomiku. Vytvorenie niekol'ko tisíc nových pracovných miest novým zahraničným investorom môže byt' totiž sprevádzané zánikom vyššieho počtu pracovných miest $\mathrm{v}$ dôsledku konkurencie neschopnosti a následného uzatvorenia niekol'kých firiem v odvetví.

Neschopnost' konkurovat' nadnárodným spoločnostiam vodvetví zo strany domácich podnikov a rovnako nespĺn̆anie štandardov kvality subdodávok pre zahraničné spoločnosti súvisí s technológiami. Ako jedna $\mathrm{z}$ výhod PZI sa uvádza technologický transfer. Technologický transfer môže byt' priamy alebo nepriamy. Priamy prebieha medzi materskou spoločnost'ou a dcérskou spoločnost'ou a nepriamy medzi nadnárodnou spoločnost'ou a domácimi podnikmi. V prípade, že nedochádza k nepriamemu technologickému transferu, hovorí sa o vytlačovaní domácich podnikov priamymi zahraničnými investíciami. K tomu, aby dochádzalo $\mathrm{k}$ technologickému transferu je samozrejme potrebná dostatočná technologická absorpčná schopnost' k krajine. Vo väčšine prípadov však k nepriamemu technologickému transferu nedochádza. Görg a Greenway (2002) poznamenávajú, že nepriamy technologický transfer nie je systematický dokazovaný ani na dlhodobých časových radoch vo svetovej ekonomike a teda tvrdenia vrospech nepriameho technologického transferu sú preceňované. Nadnárodne firmy si svoje know how chránia a bránia sa šíreniu technológií. Z toho dôvodu môže byt' tento fakt považovaný tiež za jeden z dôvodov vytlačovania domácich investícií priamymi zahraničnými investíciami v krajinách strednej a východnej Európy. Nadnárodné spoločnosti využívajúce lepšie technológie a sú schopné vyrábat' efektívnejšie v porovnaní s domácimi podnikmi.

Vt’ahovanie a vytláčanie domácich investícií priamymi zahraničnými investíciami tiež súvisí s charakterom PZI. Priame zahraničné investície plynúce do strednej a východnej Európy sú prevažne exportne orientované, čo potvrdzujú napríklad aj Djankov a Hoekman (1996), Radoševič (2002). Exportne orientované PZI bývajú spočiatku málo naviazané na hostitel'skú ekonomiku a nemajú takú tendenciu vytláčat' domáce investície v porovnaní s PZI plynúcimi do hostitel'skej ekonomiky za účelom získania tržného podielu. To však neplatí striktne a i exportne orientované PZI z dlhšieho časového hl'adiska majú tendenciu pôsobit' negatívne na domáce podniky. To potvrdzuje to, že k vytláčaniu domácich investícií v regióne SVE môže dochádzat' tiež v súvislosti s tým, že exportne orientovaní zahraniční investori nemajú tendenciu využívat' dodávatel'ské služby domácich podnikatel'ských subjektov.

\section{Pod'akovanie}

Článok vznikol za podpory programu Podpora vědy a výzkumu v Moravskoslezském kraji 2013, reg. č. RRC/05/2013, projektu dotačního titulu 3 Podpora talentovaných studentů.

\section{Literatura}

[1] AGOSIN, R. M. a R. MACHADO, 2005. Foreign Investment in Developing Countries: Does it Crowd in Domestic Investment? Oxford Development Studies, 33(2), 149-162. ISSN 1360-0818.

[2] AGOSIN, R. M. a R. MAYER, 2000. Foreign Investment in Developing Countries Does it Crowd in Domestic Investment? Discusion Paper No. 146. Geneva: UNCTAD. 
[3] DJANKOV, S. a B. HOEKMAN, 2000. Foreign Investment and Productivity Growth in Czech Enterprises. World Bank Economic Review, 14(1), 49-64. ISSN 1564-698X.

[4] GÖRG, H. a D. GREENAWAY, 2002. Much Ado about Nothing?Do Domestic Firms Really Benefit from Foreign Investment? Discusion Paper No. 3485. London: CEPR.

[5] KINDLEBERGER, C. P., 1969. American Business Abroad: Six Lectures on Direct Investment. New Haven: Yale Univesity Press. ISBN 978-0300010855.

[6] KOHOUT, P., 2005. Zahraniční investice: úspěch nebo fiasko. Lidové noviny [online]. 03. ř́ijen 2005 [vid. 18. červen 2014]. Dostupné Z: http://pavelkohout.blogspot.com/search?q=p\%C5\%99\%C3\%ADm\%C3\%A9+zahrani\%C 4\%8Dn\%C3\%AD+investice

[7] LALL, S. a P. STREETEN, 1977. Foreign Investment, Transnationals and Developing Countries. New York: Palgrave Macmillan. ISBN 978-0333168981.

[8] MIŠUN, J. a V. TOMŠÍK, 2002. Přímé zahraniční investice ve střední Evropě: vytěsňují nebo vtahují domácí investice? Politická ekonomie, 2002(2), 251-260. ISSN 0032-3233.

[9] MORRISSEY, O. a M. UNDOMKERDMONGKOL, 2008. Political Regime, Private Investment, and Foreign Direct Investment in Developming Countries. Research Paper, No. 109. Helsinki: UNU-WIDER.

[10] NEWFARMER, R. S. a W. F. MUELLER, 1975. Multinational Corporations in Brazil and Mexico: Structural Sources of Economic and Non-economic Market Power. Washington: US Government Printing Office. ASIN B006ZRM8Q6.

[11] PETROCHILOS, G., 1989. Foreign Direct Investment and the Development Process: The Case of Greece. Aldershot: Avebury. ISBN 978-0566071088.

[12] RADOŠEVIČ, S., 2002. The Electronics Inudstry in Central and Eastern Europe: an Emerging Production Location in the Alignment of Networks Perspective. Working paper, No. 21. London: SSEES.

[13] REUBER, G et al., 1973. Private Foreign Investment in Dvelopment. Oxford: Clarendon Press and OECD. ISBN 978-0198281962.

[14] ROUBÍČKOVÁ, M., 2012. Vliv institucionálního sektoru na vývoj vybraných ukazatelů. Scientific Paper of the University of Pardubice, XIX(25), 147-156. ISSN 1211-555X.

[15] SRHOLEC, M., 2004. Přmé zahraniční investice v České republice, Teorie a praxe v mezinárodním srovnání. Praha: Linde. ISBN 80-86131-52-1.

[16] TITARENKO, D., 2006. The Influence of Foreign Direct Investment on Domestic Investment Processes in Latvia. Transport and Telecomunication, 7(1), 76-83. ISSN 1407-616. 